\title{
PGR from the CPR offers a historical perspective on marine population ecology
}

\author{
R.R. Kirby* and P.C. Reid ${ }^{\dagger}$ \\ *Plymouth Marine Laboratory, Citadel Hill, The Hoe, Plymouth, PL1 2PB. 'The Sir Alister Hardy \\ Foundation for Ocean Science, 1 Walker Terrace, The Hoe, Plymouth, PL1 3BN \\ E-mail: r.kirby@pml.ac.uk
}

\begin{abstract}
The Continuous Plankton Recorder (CPR) survey has collected plankton samples from regular tracks across the world's oceans for almost 70 y. Over 299,000 spatially extensive CPR samples are archived and stored in buffered formalin. This CPR archive offers huge potential to study changes in marine communities using molecular data from a period when marine pollution, exploitation and global anthropogenic impact were much less pronounced. However, to harness the amount of data available within the CPR archive fully, it is necessary to improve techniques of larval identification, to genus and species preferably, and to obtain genetic information for historical studies of population ecology. To increase the potential of the CPR database this paper describes the first extraction, amplification by the polymerase chain reaction and utilization of a DNA sequence (mitochondrial 16S rDNA) from a CPR sample, a formalin fixed larval sandeel.
\end{abstract}

Molecular genetic analysis has already been used for the discrimination of marine invertebrate larvae (Medeiros-Bergen et al., 1995) and its use in population ecology is well known (Avise, 1994). Amplification of DNA by polymerase chain reaction (PCR) is a powerful tool in population ecology and archival material is a potentially important source of molecular data. Since most archival material is preserved in formalin, methods have been developed to enable DNA to be amplified from this material and, to date, DNA has been successfully amplified from samples up to 85-y old (Shiozawa et al., 1992; France \& Kocher, 1996; Shedlock et al., 1997; Wirgin et al., 1997; Coombs et al., 1999). However, although these methods offer great potential, few ecological questions have yet benefited from the analysis of archival specimens.

The archived database of the Continuous Plankton Recorder (CPR) survey (Warner \& Hays, 1994) represents a major resource for spatial and temporal investigations of marine populations (Reid et al., 1998; Beaugrand et al., 2000). The survey has collected plankton data from the world's seas for almost $70 \mathrm{y}$ (Warner \& Hays, 1994). CPRs are towed at 10-m depths by volunteer ships along regular tracts at monthly intervals and plankton samples are collected onto a slow moving $280-\mu \mathrm{m}$ silk mesh immersed in formalin. On return to the laboratory the silk mesh is cut into sections equivalent to ten nautical miles and the phytoplankton and zooplankton analysed; the samples are then stored in borax buffered formalin $(\sim$ pH 7.0). Since the survey began in 1931 every effort has been made to maintain the consistency and integrity of the database. Today, the archive comprises approximately 299,000 spatially extensive samples extending from a period when marine pollution, exploitation and global anthropogenic impact were much less pronounced. The ability to obtain DNA from this archival material would facilitate a major new approach to measuring long-term change in marine communities. In addition, molecular analyses will be an important aid in identifying the different larval stages of many of the planktonic species, particularly the arthropods. Therefore, to increase the potential of the CPR database, this paper describes the extraction and utilization of a DNA sequence from a formalin-fixed CPR sample.

In this initial study two methods of DNA extraction were applied to separate $10 \mathrm{mg}$ tissue samples taken from a single formalin-fixed larval sandeel (Ammodytes spp.) (CPR sample $616 \mathrm{~A} 2$ obtained from a virgin uncounted silk square stored in borax-buffered formalin): (i) a PCR-Chelex extraction technique (Coombs et al., 1999); and (ii) a modification (France \& Kocher, 1996) of the protocol developed by Shiozawa et al. (1992). Following extraction the DNA was resuspended in $50 \mu \mathrm{l}$ of sterile water. From $1 \mu 1$ of each DNA sample, partial fragments of two mitochondrial DNA (mtDNA) loci were amplified by PCR: (i) a partial fragment of the mtDNA $16 \mathrm{~S}$ rDNA gene was amplified using $10 \mathrm{pmol}$ of each of the universal amplification primers 16SAR and 16SBR (Palumbi et al., 1991); and (ii) a partial fragment on the mtDNA cytochrome- $b$ gene was amplified using primers CB1-L and CB2-H (Kocher et al., 1989). Taq DNA polymerase (Life Technologies) was used in a reaction volume of $50 \mu \mathrm{l}$. The thermal cycling conditions involved a 'hot start' with an initial denaturation of $2 \mathrm{~min}$ at $94^{\circ} \mathrm{C}$ followed by 30 cycles of $1 \mathrm{~min}$ at $94^{\circ} \mathrm{C}, 1 \mathrm{~min}$ annealing at $54^{\circ} \mathrm{C}$ and $30 \mathrm{~s}$ extension at $72^{\circ} \mathrm{C}$, and a final extension of $10 \mathrm{~min}$ at $72^{\circ} \mathrm{C}$ using an MJ Research PTC-100 thermal cycler.

$16 \mathrm{~S}$ rDNA amplification products of the expected size (614 bp) were obtained from both DNA extraction methods. However, amplification products of the expected size for cytochrome- $b$ ( $358 \mathrm{bp}$ ) were only obtained for the chelex based method. Only the $16 \mathrm{~S}$ rDNA amplification products from the chelex extraction were agarose-gel purified, polished with $P f u$ polymerase (Stratagene), cloned into the plasmid pBluescript II KS- (Stratagene) and sequenced manually (eight clones were sequenced in both orientations to determine a consensus) for verification. Comparison of the sequence to Genbank indicated the $16 \mathrm{~S}$ rDNA sequence obtained from CPR sample 616A2 (GenBank accession number: AF315121) was similar to mitochondrial 16S rDNA of the Perciformes of which the Ammodytes (sandeels) belong (Figure 1). 


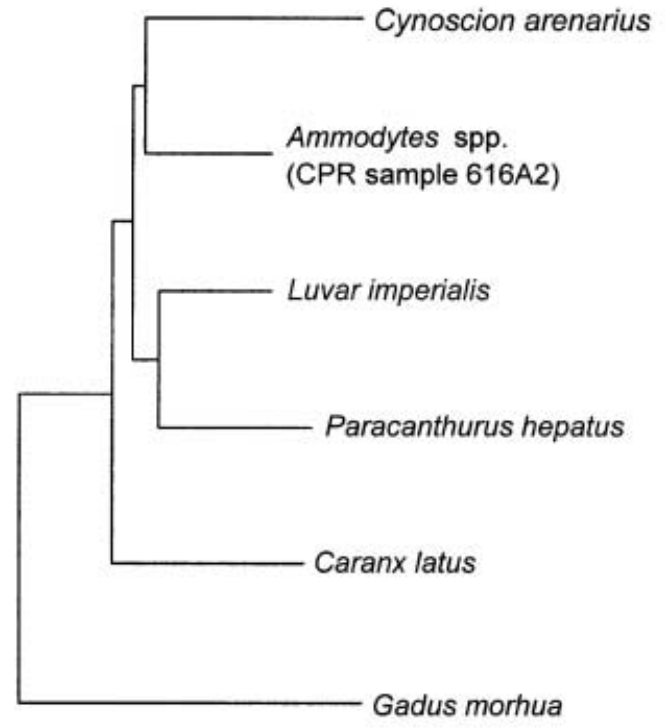

0.05 changes

Figure 1. Neighbour joining tree on Jukes-Cantor distances (Jukes \& Cantor, 1969) calculated using 511 nucleotides of aligned mitochondrial $16 \mathrm{~s}$ rDNA sequence information from each marine species and constructed using PAUP (Swofford, 2001). The unidentified larval sandeel clusters among the marine Perciformes. The tree was rooted using the mitochondrial $16 \mathrm{~S}$ rDNA sequence of the cod, Gadus morhua. The scale bar represents the number of changes per site.

The ability to obtain DNA sequence from CPR archive material represents an important advance creating new opportunities to exploit the extensive CPR archive to investigate change in the population ecology of the marine plankton communities. Immediate applications are to use the CPR archive to obtain data on intraspecific variation in DNA to examine geographical variability and long-term changes in the ecology and population dynamics of key planktonic and pelagic species. Pertinent questions and processes that can be addressed using the CPR database include recent change in fisheries and their planktonic food sources, fish larval recruitment, patterns of stock recovery following over-fishing and population differentiation. For example, to manage and conserve fish stocks successfully it is essential to know their population structure. An immediate and appropriate application of genetic techniques would be to examine change in the fish stocks of the North Sea. The North Sea fish stocks are subject to intense commercial fishing pressure and during the last seventy years have experienced great change. For example, the herring population is recovering from a total collapse of the population through overfishing, the cod is presently in severe decline and the fishery of sandeels, the largest single-species fishery in the North Sea, is so great that there is concern for the region's ecology. The GPR survey has sampled the North Sea particularly intensively over the last $70 \mathrm{y}$ and it is hoped that the techniques described above when applied to these data will help understand the population ecology of these fisheries to better aid their conservation and management.

In addition to the examination of fisheries, applications of this work also include the molecular identification of invertebrate planktonic larvae and their developmental stages. Although an identifiable larva was used for this study, the ability to use this approach to classify unidentifiable larvae represents an important advance in marine plankton ecology. For example, echinoderm and bivalve larvae are extremely difficult to identify to species, yet they are key members of ecosystems like the North Sea and are implicated in recent dramatic community changes attributed to trawling of the sea bed by the fishery (Lindeboom \& de Groot, 1998).

\section{REFERENCES}

Avise, J.C., 1994. Molecular markers. Natural history and evolution. London: Chapman \& Hall.

Beaugrand, G., Ibanez, F. \& Reid, P.C., 2000. Spatial, seasonal and long-term fluctuations of plankton in relation to hydroclimatic features in the English Channel, Celtic Sea and Bay of Biscay. Marine Ecology Progress Series, 200, 93-102.

Coombs, N.J., Gough, A.C. \& Primrose, J.N., 1999. Optimization of DNA and RNA extraction from archival formalin-fixed tissue. Nuleic Acids Research, 21, el2.

France, S.C. \& Kocher T.D., 1996. DNA sequence variation of mitochondrial large-subunit rRNA provides support for a two-subclass organization of the Anthozoa (Cnidaria). Molecular Marine Biology and Biotechnology, 5, 304-313.

Jukes, T.H. \& Cantor, G.R., 1969. Evolution of protein molecules. In Mammalian protein metabolism (ed. N.H. Munro), pp. 21-132. New York: Academic Press.

Kocher, T.D., Thomas, W.K., Meyer, A., Edwards, S.V., Pääbo, S., Villablanca, F.X. \& Wilson, A.C., 1989. Dynamics of mitochondrial evolution in animals: amplification and sequencing with conserved primers. Proceedings of the National Academy of Sciences of the United States of America, 86, 6196-6200.

Lindeboom, H.J. \& Groot, S.J. de, 1998. IMPACT-II. The effects of different types of fisheries on the North Sea and Irish Sea benthic ecosystems. NIOZ-Rapport 1998-1, RIVO-DLO Report C003/ 98. EG contract AIR2-ct94-1664.

Medeiros-Bergen, D.E., Olson, R.R., Conroy, J.A. \& Kocher, T.D., 1995. Distribution of holothurian larvae determined with species-specific genetic probes. Limnology and Oceanography, 40, 1225-1235.

Palumbi, S.A., Martin, A., Ramano, S., McMillan, W.O., Stice, L. \& Grabowski, G., 1991. The simple fool's guide to PCR, vol. 2. Honolulu, HI: University of Hawaii, Zoology Department.

Reid, P.C., Planque, B. \& Edwards, M., 1998. Is observed variability in the long-term results of the Continuous Plankton Recorder survey a response to climate change? Fisheries Oceanography, 7, 282-288.

Shedlock, A.M., Haygood, M.G., Pietsch, T.W. \& Bentzen, P., 1997. Enhanced DNA extraction and PCR amplification of mitochondrial genes from formalin-fixed museum specimens. Biotechniques, 22, 394-400.

Shiozawa, D.K., Kudo, J., Evans, R.P., Woodward, S.R. \& Williams, R.N., 1992. DNA extraction from preserved trout tissues. Great Basin Naturalist, 52, 29-34.

Swofford, D.L., 2001. PAUP*. Phylogenetic analysis using parsimony (*and other methods). Version 4. Sunderland, Massachusetts: Sinauer Associates.

Warner, A.J. \& Hays, G.C., 1994. Sampling by the Continuous Plankton Recorder survey. Progress in Oceanography, 34, 237-256.

Wirgin, I., Maceda, J., Stabile, J. \& Mesing, C., 1997. An evaluation of introgression of Atlantic coast striped bass mitochondrial DNA in a Gulf of Mexico population using formalin-preserved museum collections. Molecular Ecology, 6, 907-916.

Submitted 18 December 2000. Accepted 11 April 2001. 